\title{
PERANCANGAN PEMBELAJARAN FISIKA MENGGUNAKAN MULTIMEDIA INTERAKTIF UNTUK MENINGKATKAN MINAT MAHASISWA TERHADAP MATA KULIAH FISIKA
}

\author{
Marvin Chandra Wijaya \\ Universitas Kristen Maranatha, Bandung \\ marvinchw@gmail.com
}

Submit, 03-11-2019 Accepted, 27-12-2019 Publish, 27-12-2019

\begin{abstract}
Maranatha Christian University Computer Systems Study Program in Physics Subjects. The increase in interest uses interactive multimedia-based learning systems. The learning system is designed using the SMIL (Synchronized Multimedia Interactive Language) programming language. The physics course learning system designed in this study is course material about Object Motion (Regular Straight Motion / GLB, Irregularly Changed Straight Motion / GLBB, Free Falling Motion / GJB, Vertical Upward Motion / GVA, Vertical Down Motion / GVB). Thirty students were taken as samples to see interest in Physics courses. Data retrieval is taken before and after the provision of learning materials using interactive multimedia. The average value of interest in Physics Subjects before the use of interactive multimedia learning materials was 7.12 on a scale of 10, increasing to 8.57 after the use of interactive multimedia learning materials. Hypothesis testing uses paired t test. The results of statistical processing showed a significant increase in student interest in Physics.
\end{abstract}

Keywords: Physics Learning, Interactive Multimedia, SMIL, Object Motion

Abstrak: penelitian ini bertujuan untuk mengukur peningkatan minat mahaswa Program Studi Sistem Komputer Universitas Kristen Maranatha terhadap Mata kuliah Fisika.. Peningkatan minat tersebut menggunakan sistem belajar yang berbasis multimedia interaktif. Sistem pembelajaran tersebut dirancang menggunakan bahasa pemrograman SMIL (Synchronized Multimedia Interactive Language). Sistem pembelajaran mata kuliah Fisika yang dirancang pada penelitian ini adalah materi kuliah tentang Gerak Benda (Gerak Lurus Beraturan / GLB, Gerak Lurus Berubah Beraturan / GLBB, Gerak Jatuh Bebas / GJB, Gerak Vertikal ke Atas / GVA, Gerak Vertikal ke Bawah / GVB). Tiga puluh orang siswa diambil sebagai sampel untuk melihat minat terhadap mata kuliah Fisika. Pengambilan data dilakukan sebelum dan sesudah pemberian materi pembelajaran menggunakan multimedia interaktif. Nilai rata-rata minat ketertarikan terhadap mata kuliah Fisika sebelum penggunaan materi pembelajaran multimedia interaktif adalah 7,12 pada skala 10, meningkat menjadi 8,57 setelah penggunaan materi belajar multimedia interaktif. Pengujian hipotesis menggunakan uji t berpasangan. Hasil dari pengolahan statistik menunjukkan adanya peningkatan secara signifikan minat siswa terhadap Mata Kuliah Fisika.

Kata Kunci: Pembelajaran Fisika, Multimedia Interaktif, SMIL, Gerak Benda

\section{PENDAHULUAN}

Saat ini pembelajaran bagi anakanak sekolah tidak terbatas hanya dari kelas 1 sampai kelas 12 (SD 1 sampai dengan SMA 3), tetapi kebutuhan pendidikan tinggi sudah semakin meningkat. Persaingan di bidang ekonomi baik untuk lowongan kerja maupun untuk berwirausaha semakin lama semakin tinggi. Generasi muda perlu dipersiapkan semakin baik lagi, apalagi dengan era disruptive technology yang ada saat ini. Era saat ini sangat mudah berubah, setiap orang termasuk anak-anak muda perlu terus berubah. Change atau Perubahan adalah kata kuncinya, setiap orang tidak boleh terlena dengan zona nyamannya. 
Perubahan-perubahan harus dimulai dari dunia pendidikan (Halinger, 2003). Sistem pembelajaran saat ini harus mampu menarik minat siswa mulai dari PAUD sampai ke Perguruan Tinggi (Harahap \& Suryana, 2019). Peranperan yang penting dalam era perubahan ini terutama dalam pendidikan 4.0 dimulai dari para teknolog. Para teknolog tersebut merupakan agen of change atau agen perubahan dalam model pendidikan yang selalu berubah ini (Surani, 2019). Peran teknologi pendidikan dalam era 4.0 sangat penting.

Khususnya dalam pendidikan 4.0 perlu melakukan pemanfaatan produk teknologi. Peran teknologi yang ada berbagai macam bentuk adanya, mulai dari e-learning, pendidikan berbasis multimedia (Wijaya, 2019), dan berbagai macam bentuk yang dapat meningkatkan minat siswa terhadap suatu pelajaran atau mata kuliah seperti penggunaan perangkat lunak tertentu (Siswanto \& Azhar, 2018). Dalam rangka meningkatkan kemampuan siswa dalam pelajaran atau mata kuliah yang bersifat teknologi, perlu dimulai dengan mata kuliah dasar seperti matematika dan fisika (Trisna, 2019).

Pelajaran Fisika sangat penting terhadap peningkatan minat belajar secara keseluruhan. Sebuah penelitian yang dilakukan di SMA Negeri Karang Jaya pada tahun ajaran 2017/2018 memperlihatkan pentingnya prestasi belajar pelajaran fisika dalam meningkatkan minat belajar keseluruhan (Charli, Ariani, \& Asmara, 2019).

Sementara ini dapat dilihat pula motivasi belajar terhadap prestasi belajar IPA terpadu (Syah, Amin, \& Utami Gumay, 2019). Penelitian tersebut dilakukan pada siswa kelas VIII Mazro'illah Lubuk Linggau. Dalam penelitian tersebut memperlihatkan adanya hubungan yang signifikan antara motivasi belajar dengan prestasi belajar IPA.

Motivasi belajar seorang siswa dapat dilihat dari motivasi intrinsik (intrinsic motivation), motivasi kelas (grade motivation) percaya diri (self efficacy), teguh pendirian (self determination), dan motivasi karir (career motivation) (Sasmita, Rachman, \& Hartoyo, 2018). Motivasimotivasi tersebut merupakan hal terjadi dan berlaku bagi setiap siswa yang mempelajari pelajaran Fisika. Terlepas siswa tersebut belajar dimanapun, semua motivasi tersebut diperlukan oleh setiap siswa yang belajar fisika.

Penelitian ini mempunyai kelebihan dibandingkan dengan penelitian sebelumnya dalam mengkombinasikan teori-teori fisika dengan animasi pada multimedia interaktif. Animasi yang dibuat bersifat dinamik sehingga yang animasi tersebut dapat berubah sesuai dengan masukan paramater fisika yang diberikan.

\section{KAJIAN PUSTAKA}

Dalam rangka meningkatkan prestasi belajar untuk pelajaran fisika, telah dilakukan berbagai macam cara dan metoda. Salah satu caranya adalah dengan metoda demonstrasi. Metoda demonstrasi adalah suatu kegiatan dengan memperlihatkan kepada para pelajar suatu kegiatan atau proses, situasi atau objek tertentu yang sedang dibahas atau dipelajari. Metoda demonstrasi adalah suatu petunjuk tentang suatu kegiatan atau peristiwa dengan cara diberi contoh. Sehingga dengan metoda demonstrasi dapat membuat kegiatan atau proses tersebut dapat diketahui atau dipahami lebih baik lagi oleh para siswa (Gumay \& Bertiana, 2018).

Dalam penelitian tersebut dilakukan percobaan pada seluruh siswa kelas $\mathrm{X}$ MA Al-Muhajirin Tugumulyo. Hasil dari penelitian 
tersebut dengan metoda demonstrasi ditemukan adanya pengaruh yang signifikan terhadap hasil belajar.

Metoda yang lain yang telah diteliti adalah model pembelajaran word square. Pada model pemebelajaran word square adalah dengan memperkaya pembelajaran dan melakukan pembelajaran berorientasi pada keaktifan siswa. Model word square adalah menggabungkan kemampuan menjawab pertanyaan dengan kejelian dalam mejawab jawaban yang ada pada kotak-kotak jawaban. Penelitian ini dilakukan pada kelas VII SMPIT An-Hida Lubuk Linggau. Dari hasil penelitian ini didapatkan hasil yang signifikan terhadap prestasi belajar siswa dalam pelajaran fisika (Junaidi, Ariani, \& Arini, 2019).

Seorang guru dalam melakukan pembelajaran fisika memegang peranan penting terhadap prestasi nilai belajar. Seorang guru harus memberikan kesempatan yang seragam dan seluasluasnya kepada semua siswa untuk mengembangkan cara berpikir kreatif setiap siswa. Cara berpikir kreatif setiap siswa bersifat unik, tetapi membantu proses pembelajaran lebih baik prosesnya (Arini, 2017).

Sebuah penelitian tentang pembelajaran fisika dengan materi Konsep Listrik bagi calon guru dengan menggunakan multimedia interaktif telah dicoba pada tahun 2015. Pada penelitian tersebut calon guru yang diberikan materi Konsep Listrik menggunakan multimedia interaktif mampu menguasai materi pembelajaran dengan lebih baik (Gunawan, Harjono, \& Sutrio, 2015).

Metoda lain yang telah digunakan adalah metoda quantum teaching. Pada metoda ini mengubah cara belajar menjadi lebih meriah dengan berbagai cara dan nuansanya. Pada metoda ini segala kaitan interaksi digunakan untuk menghasilkan prestasi belajar yang lebih baik. Setiap perbedaan-perbedaan antar individu juga diperhatikan karena setiap individu itu unik. Langkah-langkah dalam quantum teaching adalah :

1. Pemberian rangsangan dalam bentuk pertanyaan tentang materi awal

2. Perumusan masalah dengan memberikan contoh-contoh yang sesuai dan ada dalam kehidupan sehari-hari.

3. Melakukan percobaan untuk mengumpulkan data dengan cara memberikan Lembar Kerja Siswa (LKS) untuk mencermati perilaku dalam kelompok belajar.

4. Menganalisa data dengan cara mencermati jawaban-jawaban pada LKS yang diberikan.

5. Guru memberikan kesempatan pada siswa untuk menampilkan dan mempresentasikan hasil belajar yang telah diperoleh.

Dengan metoda quantum teaching ini, dilakukan pada siswa kelas X SMA Negeri Jayaloka pada tahun ajaran 2017/2018. Jumlah siswa berjumlah enam kelas dengan masingmasing 32 siswa. Siswa yang memperoleh pengajaran dengan metoda quantum teaching berhasil melakukan tuntas belajar dengan kategori baik (Gumay, Heidi, \& Amin, 2018).

\section{METODE PENELITIAN}

Penelitian "Perancangan

Pembelajaran Fisika Menggunakan Multimedia Interaktif Untuk Meningkatkan Minat Mahasiswa Terhadap Mata Kuliah Fisika" diterapkan pada mahasiswa tingkat pertama Program Studi Sistem Komputer Universitas Kristen Maranatha, Bandung. Penelitian ini dibagi atas tiga tahapan penelitian, yaitu : 
1. Perancangan Multimedia Interaktif untuk materi pembelajaran Mata Kuliah Fisika dengan materi : Gerak Benda (Gerak Lurus Beraturan / GLB, Gerak Lurus Berubah Beraturan / GLBB, Gerak Jatuh Bebas / GJB, Gerak Vertikal ke Atas / GVA, Gerak Vertikal ke Bawah / GVB).

2. Percobaan pada siswa di dalam kelas Mata Kuliah Fisika. Lalu diambil data sampel mengenai minat belajar Mata Kuliah Fisika.

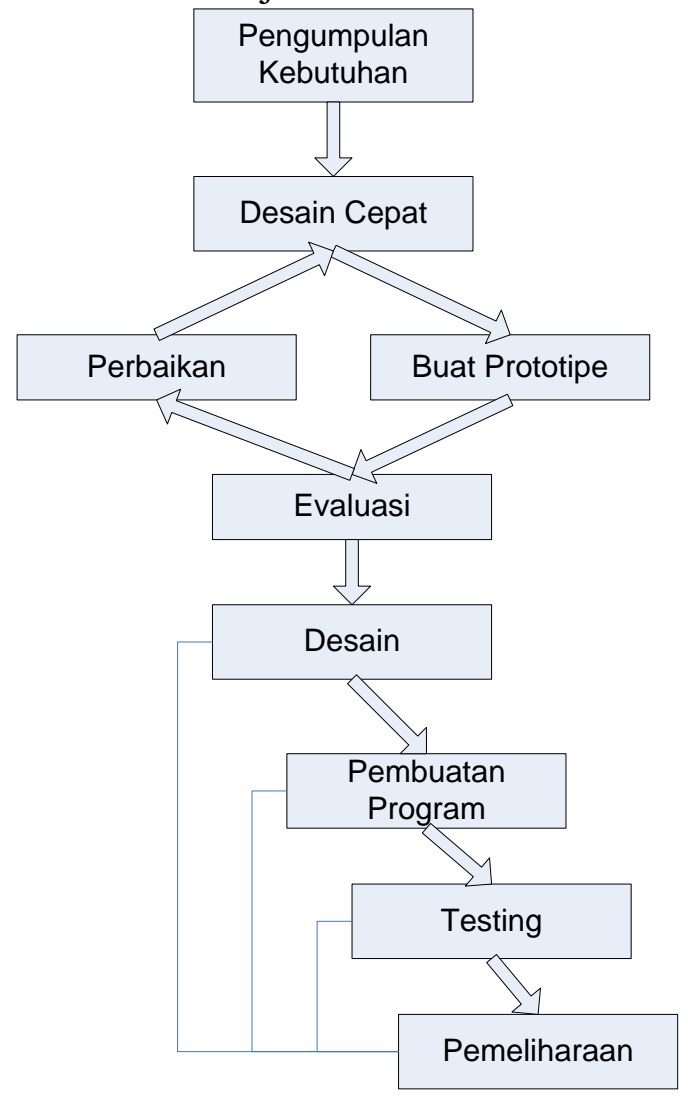

Gambar 1. Siklus Hidup Prototipe

Langkah-langkah perancangan dan pembuatan program multimedia interaktif tampak seperti pad gambar 1. Fasa-fasa dalam siklus hidup prototipe adalah :

1. Pengumpulan kebutuhan : Pada fasa ini, dilakukan pengumpulan data-data rumus-rumus gerak benda.
3. Pengujian Stastistik dari hasil pengambilan data sampel.

Tahap 1 Perancangan Multimedia Interaktif

Perancangan Multimedia interaktif ini menggunakan software engineering life cyle prototyping. Siklus hidup Prototyping adalah mempunyai langkah-langkah seperti pada gambar 1 .

1. Desain cepat : Pada fasa ini dibuat desain secara cepat antarmuka multimedia interaktif

2. Pembuatan Prototipe : Pada fasa ini diujicobakan beberapa rumusrumus gerak benda serta simulasi tampilan gerak benda.

3. Evaluasi : Pada fasa ini, dilakukan evaluasi berdasarkan masukan dari dosen pengajar Mata Kuliah Fisika

4. Perbaikan: Pada fasa ini, dilakukan perbaikan rumus-rumus serta antarmuka tampilan berdasarkan fasa evaluasi

5. Desain : Pada fasa ini, dibuat desain dengan lebih detail dari proses perhitungan rumus-rumus gerak benda dan simulasi tampilannya.

6. Pembuatan program : Pada fasa ini, dibuat program menggunakan bahasa pemograman Synchornized Multimedia Integration Language (SMIL).

7. Testing : Pada fasa ini, multimedia interaktif yang dibuat diujicobakan oleh dosen pengajar Mata Kuliah Fisika.

8. Pemeliharaan : Pada fasa ini, dilakukan proses persiapan untuk 
instalasi perangkat lunak yang dibuat.

Pada fasa desain dilakukan proses perancangan menggunakan diagram alir. Diagram alir yang dirancang untuk pembuatan multimedia interaktif untuk materi gerak benda adalah seperti pada gambar 2.

Program multimedia yang dibuat, pertama-tama akan menampilkan video tentang pengenalan gerak benda, setelah itu akan muncul pilihan untuk memilih jenis gerak benda yang akan dipelajari lebih lanjut. Setiap pilihan gerak benda yang dipilih oleh siswa akan menampilkan penjelasan lebih lanjut untuk masing-masing gerak benda tersebut.

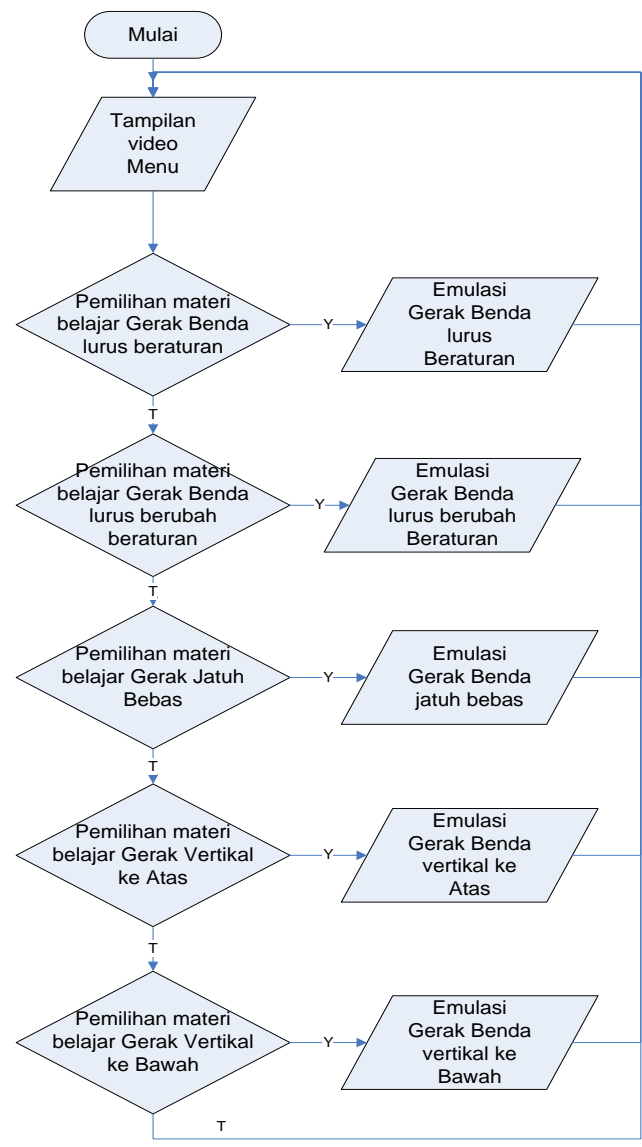

Gambar

2. Diagram Alir Perancangan
Program
Tahap 2 Percobaan pada siswa di dalam kelas Mata Kuliah Fisika

Program Multimedia Interaktif dengan materi pembelajaran gerak benda, diujicobakan di dalam kelas Mata Kuliah Fisika yang terdiri dari 30 siswa. Langkah-langkah yang dilakukan adalah:

1. Diawal perkuliahan setiap siswa diminta untuk mengisikan survei minat / interest / ketertarikan siswa dalam belajar Mata Kuliah Fisika.

2. Lalu diberikan pengajaran bukan dalam bentuk biasa, tetapi dalam bentuk multimedia interaktif.

3. Diakhir perkuliahan siswa diminta kembali mengisi survei yang berisi minat / interest / ketertarikan siswa dalam mempelajari Mata Kuliah Fisika.

\section{Tahap 3 Pengujian Stastistik dari hasil pengambilan data sampel}

Data-data yang didapat dilakukan uji statistik dengan metoda uji $t$ sampel berpasangan (pairedsample $t$ test). Uji $t$ sampel berpasangan berfungsi untuk membandingkan dua variabel untuk suatu grup tunggal. Uji $t$ sampel berpasangan menghitung selisih antara nilai dua variabel dan menguji selisih rata-rata tersebut bernilai nol. Rumus (1) adalah rumus dari uji t sampel berpasangan.

$$
t=\frac{\bar{d}}{s_{d} / \sqrt{n}}
$$

dimana :

$\mathrm{t}=$ nilai uji

$\overline{\mathrm{d}}=$ nilai rata-rata selisih

$\mathrm{s}_{\mathrm{d}}=$ standar deviasi dari $\mathrm{d}$

$\mathrm{n}=$ banyak sampel

derajat bebas / degree of freedom $=\mathrm{n}-1$ 


\section{HASIL PENELITIAN}

Program Multimedia interaktif dimulai dengan video awal tentang gerak benda seperti pada gambar 3 . Video tersebut menampilkan berbagai macam jenis gerak benda benda. Kemudian muncul tampilan pilihanpilihan untuk masing masing jenis gerak benda (GLB, GLBB, GJB, GVA dan GVB). Siswa dapat memilih materi yang ingin dipelajari.

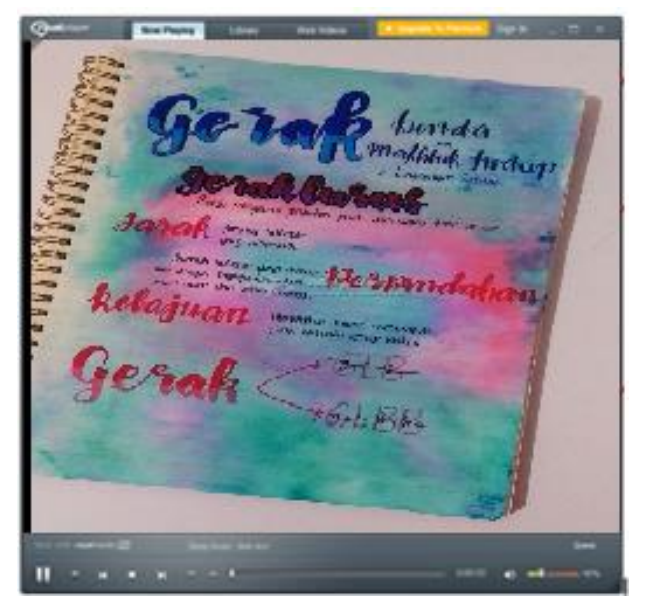

Gambar 3. Tampilan video awal

Ketika siswa memilih salah satu materi pilihan maka akan muncul video tentang jenis gerak benda tersebut. Gambar 4 dan gambar 5 menampilkan video dan rumus gerak jatuh bebas. Gambar 6 menampilkan simulasi video gerak benda lurus beraturan

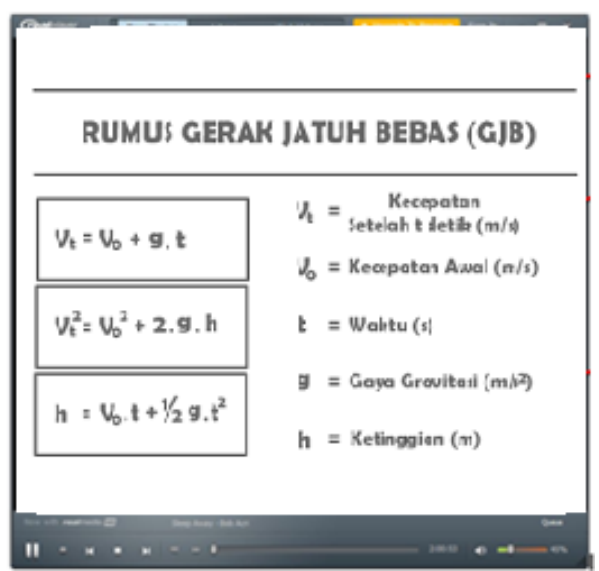

Gambar 4. Tampilan rumus GJB

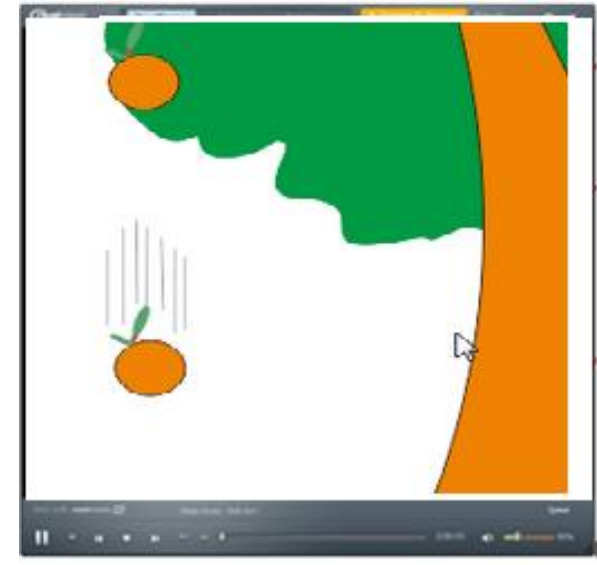

Gambar 5. Simulasi gerak jatuh bebas

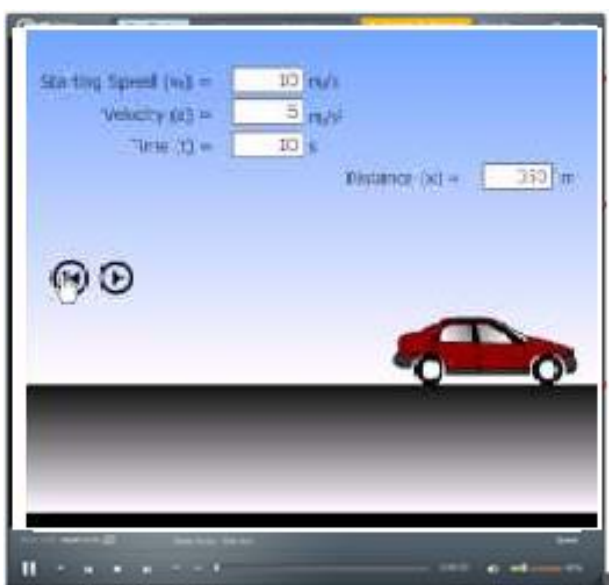

Gambar 6. Simulasi gerak lurus beraturan

Tabel 1 menunjukkan pengambil dana minat ketertarikan siswa belajar Mata Kuliah Fisika. Siswa diminta mengisikan angka 1 10 (angka 1 berarti sangat tidak tertarik, angka 10 berarti sangat tertarik)

Tabel 1. Ketertarikan minat belajar fisika

\begin{tabular}{ccc}
\hline Siswa & Sebelum & Sesudah \\
\hline 1 & 6 & 8 \\
2 & 7 & 8 \\
3 & 6 & 9 \\
4 & 8 & 9 \\
5 & 5 & 7 \\
6 & 6 & 8 \\
7 & 7 & 8 \\
8 & 8 & 10 \\
9 & 6 & 8 \\
10 & 7 & 9 \\
11 & 8 & 9 \\
12 & 6 & 7 \\
13 & 7 & 8 \\
14 & 5 & 7
\end{tabular}




\begin{tabular}{ccc}
15 & 8 & 10 \\
16 & 9 & 10 \\
17 & 10 & 10 \\
18 & 6 & 8 \\
19 & 7 & 7 \\
20 & 8 & 8 \\
21 & 8 & 9 \\
22 & 9 & 9 \\
23 & 6 & 8 \\
24 & 7 & 8 \\
25 & 8 & 10 \\
26 & 9 & 10 \\
27 & 10 & 10 \\
28 & 6 & 8 \\
29 & 7 & 8 \\
30 & 7 & 9 \\
\hline
\end{tabular}

Pengolahan data yang ada pada tabel 1 dilakukan menggunakan perangkat lunak SPSS. Hasil dari pengolah SPSS adalah seperti pada tabel 2, tabel 3 dan tabel 4 .

Tabel 2. Statistik sampel

\begin{tabular}{lcc}
\hline & Rata-Rata & Std. Dev. \\
\hline Sebelum & 7,23 & 1,331 \\
Sesudah & 8,57 & 1,006 \\
\hline
\end{tabular}

Terlihat pada tabel 2 nilai ratarata ketertarikan siswa belajar Mata Kuliah Fisika untuk sebelum diberikan materi kuliah dalam bentuk multimedia interaktif adalah 7,23 (pada skala 10) dan sesudah diberikan dalam bentuk multimedia interaktif adalah 8,57 (pada skala 10)

Tabel 3. Statistik Selisih

\begin{tabular}{ccc}
\hline & Rata-Rata & Std. Dev. \\
\hline Sebelum-Sesudah & $-1,333$ & 0,802 \\
\hline
\end{tabular}

Tabel 4. Uji t dengan $\mathrm{df}=29$

\begin{tabular}{ccccc}
\hline & Lower & Upper. & $\mathrm{t}$ & sig \\
\hline $\begin{array}{c}\text { Sebelum- } \\
\text { Sesudah }\end{array}$ & $-1,633$ & $-1,034$ & $-9,103$ & 0,000 \\
\hline
\end{tabular}

Pada tabel 3 dan tabel 4 adalah perhitungan menggunakan SPSS untuk uji $\mathrm{t}$ berpasangan dengan tingkat keyakinan 95\%. Pada hasil akhir perhitungan didapat nilai signifikansi $0,000<0,050$ yang berarti ada nilai siginifikan perubahan minat belajar Mata Kuliah Fisika lebih baik dengan menggunakan Multimedia interaktif.

\section{PEMBAHASAN}

Indikator pengaruh minat ketertarikan dipengaruh oleh dukungan akademik (academic support), dukungan sosial (social support) dan dukungan lingkungan (environment support) (Maivalinda \& Srihasinita, 2016). Dalam penelitian ini telah dilakukan peningkatan minat pada bidang dukungan akademik. Perlu ada penelitian lebih lanjut dalam bidang sosial dan lingkungan untuk meningkatkan minat ketertarikan siswa terhadap mata kuliah Fisika.

Peningkatan minat merupakan dasar atau awal dalam rangka memperbaiki kemampuan siswa untuk memahami materi mata kuliah Fisika. Dengan peningkatan minat siswa maka inovasi, kreatifitas, kemampuan memecahkan masalah (problem solving) siswa terhadap mata kuliah siswa akan meningkat (Ghazali, Ibrahim, \& Zainol, 2012).

\section{SIMPULAN}

Adanya peningkatan minat keteratarikan yang signifikan untuk belajar Mata Kuliah Fisika dengan metoda multimedia interaktif di Program Studi Sistem Komputer, Universitas Kristen Maranatha.

\section{DAFTAR PUSTAKA}

Arini, W. (2017). Analisis Kemampuan Berpikir Kreatif pada Materi Cahaya Siswa Kelas Delapan Smp Xaverius Kota Lubuklinggau. Science and Physics Education Journal (SPEJ), 1(1), 23-38. https://doi.org/10.31539/spej.v $1 \mathrm{i} 1.41$ 
Charli, L., Ariani, T., \& Asmara, L. (2019). Hubungan Minat Belajar terhadap Prestasi Belajar Fisika. Science and Physics Education Journal (SPEJ), 2(2), 52-60. https://doi.org/10.31539/spej.v 2i 2.727

Ghazali, Z., Ibrahim, N. A., \& Zainol, F. A. (2012). Factors affecting entrepreneurial intention among UniSZA students. Asian Social Science, 9(1), 85-93. https://doi.org/10.5539/ass.v9n $1 \mathrm{p} 85$

Gumay, O. P. U., \& Bertiana, V. (2018). Pengaruh Metode Demonstrasi terhadap Hasil Belajar Fisika Kelas X MA Almuhajirin Tugumulyo. Science and Physics Education Journal (SPEJ), 1(2), 96-102. https://doi.org/10.31539/spej.v $1 \mathrm{i} 2.272$

Gumay, O. P. U., Heidi, N., \& Amin, A. (2018). Efektivitas Model Pembelajaran Quantum Teaching terhadap Hasil Belajar Fisika. Science and Physics Education Journal (SPEJ), 2(1), 36-41. https://doi.org/10.31539/spej.v $2 \mathrm{i} 1.465$

Gunawan, G., Harjono, A., \& Sutrio, S. (2015). Multimedia Interaktif dalam Pembelajaran Konsep Listrik bagi Calon Guru. Jurnal Pendidikan Fisika Dan Teknologi, 1(1), 9-14. https://doi.org/10.29303/jpft.v1 i1.230

Halinger, P. (2003). Leading Educational Change: reflections on the practice of instructional and transformational leadership. Cambridge Journal of Education, 33(3), 329-352. https://doi.org/10.1080/030576
4032000122005

Harahap, M., \& Suryana, D. (2019). Basis Pengetahuan Kurikulum Guru PAUD di Era Pendidikan 4.0.

Junaidi, J., Ariani, T., \& Arini, W. (2019). Pengaruh Model Pembelajaran Word Square terhadap Hasil Belajar Fisika. Science and Physics Education Journal (SPEJ), 2(2), 72-81. https://doi.org/10.31539/spej.v $2 \mathrm{i} 2.726$

Maivalinda, \& Srihasinita, R. (2016). Mengukur Minat Kewirausahaan Mahasiswa Fakultas Eksakta Dan Non Eksakta Universitas Andalas (Menghadapi Tantangan Ekonomi Kreatif). UNES Journal of Social and Economic Research, 1(2), 112.

Sasmita, P. R., Rachman, S., \& Hartoyo, Z. (2018). Analisis Motivasi Mahasiswa dalam Belajar Fisika. Science and Physics Education Journal (SPEJ), 1(2), 89-95. https://doi.org/10.31539/spej.v 1i2.269

Siswanto, R. D., \& Azhar, E. (2018). Workshop Penerapan Software GeoGebra Sebagai Media Pembelajaran Matematika Untuk Guru Sekolah Dasar Kelurahan Pademangan Barat. Publikasi Pendidikan, 8(3), 224.

https://doi.org/10.26858/publik an.v8i3.6421

Surani, D. (2019). Studi literatur: Peran teknolog pendidikan dalam pendidikan 4.0. Prosiding Seminar Nasional Pendidikan FKIP, 2(1), 456469. 
Syah, D. N., Amin, A., \& Utami

Gumay, O. P. (2019).

Hubungan Motivasi Belajar terhadap Prestasi Belajar IPA Terpadu. Science and Physics Education Journal (SPEJ), 2(2), 66-71. https://doi.org/10.31539/spej.v $2 \mathrm{i} 2.724$

Trisna, B. N. (2019). Pendidikan 4.0: Perubahan Paradigma dan Penguatan Kearifan Lokal Dalam Pembelajaran Matematika. Math Didactic: Jurnal Pendidikan Matematika, 5(1), 83-92. https://doi.org/10.33654/math.v 5 i1.519

Wijaya, M. C. (2019). Dampak Penggunaan Media Pembelajaran Berbasis Multimedia Interaktif pada Komunikasi Pengajar dan Siswa di Bandung. Journal Pekommas, 4(1), 53-60. https://doi.org/10.30818/jpkm. 2019.2040106 